\title{
Emendas Constitucionais e Restrições aos Direitos Fundamentais
}

Rodrigo Brandão'

\section{Introdução. Preliminares teóricas. Norma e enunciado normativo}

A circunstância de a Constituição de 1988 haver positivado como cláusulas pétreas, entre outras matérias, os "direitos e garantias individuais", traz uma série de questōes hermenêuticas relevantes. ${ }^{2}$ Destacam-se as indagações referentes à possibilidade jurídica, ou não, de emendas constitucionais alterarem os dispositivos que prevêem tais direitos; em caso positivo, se tais alteraçōes só seriam cabíveis se destinadas a aprimorar a tutela dos direitos individuais ou, se, ao revés, intervenções de caráter restritivo também seriam admissíveis; e, por fim, caso se responda afirmativamente também à última questão, resta saber quais seriam os limites impostos a tais restrições. $\mathrm{O}$ adequado tratamento dessas questōes - objeto central do presente artigo - pressupõe, todavia, o esclarecimento de algumas premissas teóricas.

A primeira dissociação que se impõe se refere aos conceitos de dispositivo e de norma. Efetivamente, uma das pedras de toque da moderna hermenêutica

\footnotetext{
Procurador do Município do Rio de Janeiro. Mestre em Direito Público pela UERJ, Coordenador do Núcleo de Estudos de Direito Constitucional da PGM/RJ e Professor de Direito Constitucional da EMERJ, do IBMEC, do Praetorium, do CEJ e da ESAP.

2 Parte-se da premissa, compartilhada pelo STF no julgamento da ADIn n ${ }^{\circ}$ 939-DF, de que a expressão direitos e garantias individuais, inserta no art. 60, p. 4, IV, da Constituiçāo, deve ser lida como direitos fundamentais, abrangendo inclusive os não positivados formalmente no respectivo catálogo constitucional, mercê da cláusula materialmente aberta contida no art. $5^{\circ}, \$ 2^{\circ}$, da Constituiçāo de 1988. V. ADIn n" 939-DF, Tribunal Pleno, STF, RTJ 151, p. 755, assim ementada: "I - Uma Emenda Constitucional, emanada, portanto, de Constituinte derivada, incidindo em violação à Constituição originária, pode ser declarada inconstitucional, pelo Supremo Tribunal Federal, cuja função própria é a guarda da Constituição (art. 102, I, a, da CF)."
} 
jurídica consiste na noção de que o dispositivo ou texto normativo é objeto da atividade interpretativa, enquanto as normas são o resultado deste processo, é dizer, o sentido construído a partir da interpretaçāo dos textos normativos. Daí não haver correspondência necessária entre dispositivo e norma, pois não se afiguram verdadeiras as assertivas de que sempre que houver um dispositivo há uma, e somente uma, norma, bem como de que toda norma corresponde a um único dispositivo. Com efeito, há casos (i) em que são identificadas normas sem o correlato dispositivo (princípios implícitos; $v$. g.: princípio da proteçāo da confiança); (ii) há dispositivos que não contêm normas (proteção de Deus, prevista no preâmbulo da Constituição de 1988); (iii) há dispositivos que contêm mais de uma norma (do art. 150, I, CF/88 - exigência de lei para instituição e aumento de tributos - decorrem os princípios da legalidade, da tipicidade, proibição de regulamentos autônomos e vedação à delegação legislativa); e, enfim, (iv) há casos em que é necessária a aglutinação de diferentes dispositivos para a formação de uma só norma (constrói-se o princípio da segurança jurídica a partir dos dispositivos que garantem a legalidade, a irretroatividade e a anterioridade). ${ }^{3}$

Do exposto é possível inferir que a mera modificação, por emenda constitucional, de dispositivo referente a direito fundamental não traduz, necessariamente, eiva de inconstitucionalidade, ${ }^{4}$ porquanto não gera, de per se, prejuízo ao conteúdo ou à tutela do direito fundamental respectivo. Ao contrário, a eventual invalidade da intervenção legislativa há de derivar da sua repercussão sobre o conteúdo da norma de direito fundamental. Contudo, cumpre repisar a indagação a respeito de as inovaçōes incidentes sobre as normas de direitos fundamentais terem a sua constitucionalidade limitada às hipóteses de incremento da proteção ou de mera configuração do direito, ou, se, ao contrário, efetivas restrições são também toleradas. À guisa de esclarecimento, convém salientar que se utiliza o termo configuração para designar as intervenções legislativas destinadas, meramente, a densificar, regulamentar, ou concretizar o conteúdo normativo do direito, "realizada(s) por meio do detalhamento de seu conceito, da especificaçāo de suas formas de exercício e do estabelecimento de garantias processuais aptas a afastá-lo". ${ }^{5}$ Já restriçāo se refere à efetiva redução do âmbito inicialmente protegido das posiçōes jurídicas fundamentais, ${ }^{6}$ pois o que era conteúdo do direito antes da restrição deixa de sê-lo após a sua efetivação. ${ }^{7}$

3 Esta formulação, assim como os exemplos utilizados, sāo da lavra de Humberto Ávila. V. ÁVILA, Humberto Bergman. Teoria dos princípios: da definiçāo à aplicaçāo dos princípios jurídicos. 4. ed. São Paulo: Malheiros Editores, 2004. p. 22-23.

4 SARLET, Ingo Wolfgang. Direitos sociais: o problema de sua proteção contra o poder de reforma na Constituiçāo de 1988. Revista de Direito Constitucional e Internacional, ano 12, $\mathrm{n}^{\circ} 46, \mathrm{p} .333-395$, jan./mar. 2004; MENDES, Gilmar Ferreira. Plebiscito - EC 2/92 (Parecer), Revista Trimestral de Direito Público, p. 108 ss, 7/105/1994.

5 PEREIRA, Jane Reis Gonçalves. Interpretaçāo constitucional e direitos fundamentais. Rio de Janeiro: Renovar, 2006. p. 138.

- ALEXY, Robert. Teoría de los derechos fundamentales. Madrid: Centro de Estudios Constitucionales, 1997. p. 272.

BOROWSKI, Martin. La estructura de los derechos fundamentales. Bogotá: Universidad Externado de Colombia, 2003. p. 69. 
Cumpre ressaltar que a metodologia jurídica contemporânea oferece respostas contraditórias acerca da possibilidade da introdução de restrições constitucionalmente legítimas aos direitos fundamentais. Digladiam-se, no particular, as chamadas teorias interna e externa, as quais serão delineadas, de forma esquemática e simplificada, nas seguintes linhas.

\section{A viabilidade jurídica de o legislador (constituinte-reformador ou ordinário) impor restrições aos direitos fundamentais. $O$ embate entre as teorias interna e externa}

A teoria interna considera corolário lógico dos conceitos de rigidez e de supremacia constitucional a negativa da possibilidade de o legislador imprimir efetivas restrições aos direitos fundamentais, porquanto tal medida subverteria a hierarquia das fontes do direito, implicando supervalorização da lei e de normas infraconstitucionais em detrimento das normas constitucionais, com as quais aquelas seriam diretamente sopesadas. ${ }^{8}$ Com efeito, estando os direitos fundamentais protegidos por normas constitucionais, a admissão de que a lei, espécie normativa hierarquicamente inferior àquelas, restrinja direito fundamental, parece contrastar com a supremacia da Constituição sobre as demais normas.

Pelas mesmas razões, poder-se-ia argumentar que o reconhecimento da viabilidade de o constituinte reformador introduzir efetivas limitações nas cláusulas pétreas representaria a confissão da sua inocuidade, já que tais cláusulas foram concebidas, precisamente, como limites materiais ao poder de reforma da Constituição. De conseguinte, caberia tão-somente ao legislador (ordinário ou constituinte-reformador) configurar os direitos fundamentais, especificando-os dentro do conteúdo constitucionalmente previsto. Só há de admitir-se em seu favor a prerrogativa de, efetivamente, efetuar restrição a direito fundamental, quando a própria Constituição contiver expressa autorização para tanto. ${ }^{9}$

Saliente-se, por relevante, que a teoria interna pressupõe a existência de um direito com conteúdo predeterminado constitucionalmente, de maneira que toda posição que exceda tal âmbito de proteção não será objeto de tutela jurídica. Assim, cumpre ao aplicador do direito a tarefa de verificar se o "conteúdo aparente do direito" é também o seu "conteúdo verdadeiro", promovendo, apenas aparentemente, um exame bifásico, semelhante ao preconizado pela teoria externa. Com

\footnotetext{
Esta assertiva de Friedrich Muller foi colhida por PULLIDO, Carlos Bernal. El principio de proporcionalidad y los derechos fundamentales: el principio de proporcionalidad como criterio para determinar el contenido de los derechos fundamentales vinculante ao legislador. Madrid: Centro de Estudios Políticos y Constitucionales, 2003. p. 444.

- PEREIRA, Jane Reis Gonçalves. Op. cit., p. 140. A constitucionalista carioca ressalva, contudo, que este ponto é controvertido entre os adeptos da teoria interna. Posicionam-se no sentido assinalado no corpo do texto Friedrich Muller e Ignácio Otto y Pardo; em sentido diverso, Antonio Luis Martinez Pujalde.
} 
efeito, em ambos os casos verifica-se, inicialmente e à luz do caso concreto, se o conteúdo aparente (ou prima facie, segundo a teoria externa) do direito foi afetado; em seguida, deve-se decidir se o conteúdo aparente do direito coincide com o seu conteúdo verdadeiro (ou definitivo, segundo a teoria externa).

A diferença fundamental consiste em que o conteúdo aparente não abrange posições juridicamente protegidas, mas cuida simplesmente de artifício destinado a elucidar o conteúdo predeterminado constitucionalmente, enquanto o conteúdo prima facie oferece, inicialmente, proteçāo jusfundamental, que é afastada por norma restritiva, decorrente da prevalência em concreto de outros direitos ou princípios constitucionais. Em uma só palavra: quem invoca um direito aparente atua sem direitos, e não com direitos restringidos por outros direitos ou valores constitucionais. ${ }^{10}$ Não há que se falar, portanto, em recortes ao conteúdo inicialmente protegido do direito fundamental impostos por outros direitos ou princípios (limites externos), mas apenas de limites intrínsecos aos direitos (limites internos ou imanentes), que excluem determinadas situações do seu âmbito de proteção. ${ }^{11}$

Os limites internos, assim,

"não são barreiras ao exercício do direito que reduzem o seu espaço natural e original, mas [...] fronteiras que delimitam o seu conteúdo, de sorte que fora dele não há nem nunca houve direito". Os limites externos, por sua vez, teriam origem na necessidade de harmonizar os conflitos entre direito fundamental e outros direitos fundamentais ou princípios constitucionais. Seriam, portanto, impostos desde fora do direito fundamental, [...] não estando determinados pela conceitualização do direito em jogo, como no caso dos limites internos $[\ldots] .{ }^{12}$

A conseqüência do que se expôs é que a teoria interna nega os conflitos entre direitos fundamentais e, por conseguinte, a ponderação de interesses como método apto a solvê-los. Considera, por sua vez, que a aplicação dos direitos fundamentais deve se dar mediante a identificaçāo do conteúdo constitucionalmente estabelecido e a verificação da sua adequação concreta à situação em tela, utilizando-se, notadamente, os elementos sistemático e teleológico. ${ }^{13} \mathrm{~A}$ bem da verdade,

\footnotetext{
10 BOROWSKI, Martin. Op. cit., p. 69.

1 ALEXY, Robert. Op. cit., p. 269.

12 CIANCIARDO, Juan. El conflictivismo en los derechos fundamentales. Pamplona: EUNSA, 2000. p. 227. O trecho referente aos limites internos foi colhido por Cianciardo de RODRÍGUEZ-TOUBES MUÑIZ, J. La razón de los derechos, Madrid: Tecnos, 1995. p. 69-70.

13 Em preciosa síntese, salienta Ana Paula de Barcellos que, dentre os autores que negam - total ou parcialmente - a realidade dos conflitos normativos, há, basicamente, duas propostas alternativas à ponderação, quais sejam, as teorias dos limites imanentes (t.1) e da conceptualizaçāo (t.2). A teoria dos limites imanentes (t. I) "sustenta que cada direito apresenta limites lógicos, imanentes, oriundos da própria estrutura e natureza do direito e, portanto, da própria disposiçāo que o prevê", qualificando-se, portanto, como limites internos. O delineamento desses limites, contudo, é feito de forma "quase intuitiva e está relacionada com a evidência desses limites para o senso comum". Por outro lado, os conceptualistas (t.2) salientam que a admissão de que os direitos fundamentais colidam entre
} 
convém destacar que o leitmotiv da teoria interna consiste em frontal crítica ao subjetivismo que seria inerente à técnica da ponderação de bens, o qual causaria prejuízo à segurança jurídica e ao princípio democrático, porquanto juízes despidos de legitimidade democrática editariam, a posteriori e sem qualquer parâmetro objetivo, a norma jurídica concreta destinada a reger a hipótese que lhe foi submetida. Consideram, inversamente, que o processo de verificação da adequação dos fatos ao conteúdo constitucionalmente protegido conferiria maior objetividade e racionalidade à atividade judicial, reduzindo o risco de decisionismo. ${ }^{14}$

Saliente-se, por fim, que os adeptos da teoria interna sustentam que a teoria externa, ao alargar sobremaneira o âmbito de proteção inicial dos direitos fundamentais, considerando que as situações aí inseridas somente perderiam a proteção jusfundamental mediante restrição imposta por outros direitos fundamentais ou por princípios constitucionais, geraria, de uma só vez, (i) "uma inflação de direitos fundamentais", que debilitaria a sua força normativa, (ii) uma "multiplicação de litígios jusfundamentais", muitos deles alusivos a "falsos casos constitucionais", da qual decorreria (iii) uma ampliação excessiva das competências da Corte Constitucional. ${ }^{15}$

Singularmente ilustrativo do alvitrado inflacionamento dos direitos fundamentais é o exemplo do artista que resolve realizar uma pintura em um cruzamento de ruas bastante movimentado, da lavra de Friedrich Muller. ${ }^{16}$ Apesar de

si e com outros princípios constitucionais que veiculam bens coletivos ou finalidades públicas parte de uma premissa individualista e liberal, que se revela equivocada por superlativizar o âmbito de proteção desses direitos em detrimento da sua finalidade social e da sua historicidade. Assim, preconizam que o intérprete persiga o conceito do direito para além da literalidade do dispositivo que o consagra, em cuja tarefa deverá atentar para "a função social e histórica do direito e seus fins lógicos, além da própria necessidade de convivência com outros direitos. Uma vez delineados os conceitos dos diferentes direitos, não haverá conflito entre eles ou entre eles e exigências associadas ao interesse coletivo". Desta feita, assim como os autores que esposam a teoria dos limites imanentes, os teóricos do conceptualismo afastam as idéias de conflitos e de limites externos aos direitos fundamentais, muito embora se perceba distinção relevante na demarcação dos limites internos dos direitos fundamentais, conforme pode se inferir do diferente itinerário percorrido no delineamento dos limites imanentes (t.1) e dos conceitos dos direitos fundamentais (t.2), tal qual exposto linhas acima. BARCELLOS, Ana Paula. Ponderação, racionalidade e atividade jurisdicional. Rio de Janeiro: Renovar, 2005. p. 57-66.

it OTTO Y PARDO, Ignacio de. La regulación del exercício de los derechos y liberdades: la garantía de su contenido esencial en el articulo 53.1 de la constitución. In: MARTÍN-RETORTILLO, Lorenzo; OTTO Y PARDO, Ignacio de. Derechos fundamentales y constitución. Madrid: Civitas, 1992. p. 123-124.

; CIANCIARDO, Juan. El conflictivismo en los derechos fundamentales. Pamplona: EUNSA, 2000. p. 245-246.

16 MULLER, Friedrich. Die Positivität der Grundrechte, p. 74 apud ALEXY, Robert. Op. cit., p. 303 ss. Muller funda a sua auto-intitulada "teoria estrutural pós-positivista da norma jurídica" na distinção entre norma e texto normativo. Assim, a interpretaçāo do texto da norma, mediante o emprego dos elementos gramatical, histórico, genético, sistemático e teleológico e dos princípios de interpretação constitucional, revelaria apenas o "programa normativo". Após a definição do "programa normativo", a atividade de concretização da norma pressuporia que o intérprete atentasse também para o "âmbito normativo", elemento normativo de igual hierarquia àquele, que se consubstanciaria no setor da realidade social abrangido pela regulamentação jurídica. V. MULLER, Friedrich. Métodos de trabalho do direito constitucional. 2. ed. São Paulo: Max Limonad, 2000. Especificamente quanto aos direitos fundamentais, salienta Muller: "Los derechos fundamentales son garantías de protección objetivamente acuñadas, de 
a atividade de pintar, enquanto tal, ser objeto de proteção da liberdade artística, a ação específica de pintar em um cruzamento com tráfego intenso não se amolda ao âmbito normativo desta liberdade fundamental, de maneira que a lei que proíba tal atividade não se consubstanciará em medida restritiva de direito fundamental, mas simplesmente em norma que estatui obrigação para além do conteúdo constitucionalmente protegido da liberdade artística. Evitam-se, assim, as pseudocolisões e todos os prejuízos delas decorrentes à segurança jurídica, ao princípio democrático, à força normativa dos direitos fundamentais e à excessiva ampliação das competências das Cortes Constitucionais.

Enquanto a teoria interna pressupõe a existência de um único objeto jurídico, qual seja, o conteúdo verdadeiro do direito, constitucionalmente estabelecido e apenas configurado pelo legislador, a teoria externa trabalha com dois objetos jurídicos: o direito prima facie e a restrição a tal direito, tendo-se como resultado desta interface o direito definitivo. O processo de interpretação e aplicação dos direitos fundamentais seria, portanto, efetivamente bifásico: primeiro, verifica-se se a situação em apreço insere-se, ou não, no conteúdo prima facie do direito; constatado o acoplamento, indaga-se, então, se o direito prima facie foi restringido, no caso concreto, por limites externos impostos por outros direitos ou princípios constitucionais, de forma a excluir-se a presença de um direito definitivo. ${ }^{17}$ Assim, uma situação concreta somente será considerada permitida na hipótese de amoldar-se ao conteúdo prima facie do direito e de não ser albergada por restrição. ${ }^{18}$

Salienta, com acuidade, Jane Reis Gonçalves Pereira que

Na primeira fase, o intérprete deve determinar, da forma mais ampla possivel, as diversas faculdades e posiçōes jurídicas que decorrem do direito fundamental em jogo. Trata-se de verificar, à luz do dispositivo que assegura o direito, seu "conteúdo inicialmente protegido", sem tomar-se em consideração se outros direitos individuais ou interesses comunitários podem ser afetados ou restringidos. A leitura da norma, nessa etapa, deve ser a mais ampliativa possível. Sem embargo, devem ser levadas em consideração as limitaçōes estabelecidas no próprio preceito que outorga o direito (por exemplo, a esfera de proteção do direito de associação só ampara as constituídas para "fins lícitos", vedando, ab initio, as de caráter paramilitar). ${ }^{19}$

determinados complexos individuales y sociales concretos de acción, organización y de materias. Estos 'ámbitos materiales' son constituídos em 'ámbitos normativos' por el reconocimento y garantía de las libertades constitucionales dentro del marco de la regulación normativa, del 'programa normativo' iusfundamental. Los ámbitos normativos participan en la normatividad práctica, es decir, son elementos codeterminantes de la decisión jurídica"; MULLER, Friedrich. Die Positivität der Grundrechte, p. 11 apud ALEXY, Robert. Op. cit., p. 74-75. Para uma análise mais detida do método normativo-estruturante de Muller, V. SOUZA NETO, Cláudio Pereira. Jurisdição constitucional, democracia e racionalidade prática. Rio de Janeiro: Renovar, 2002. p. 197-208.

: BOROWSKI. Martin. Op. cit.

18 ALEXY, Robert. Op. cit., p. 298.

19 PEREIRA, Jane Reis Gonçalves. Op. cit., p. 147. 
Na segunda etapa, por sua vez, caberia sopesar o direito prima facie com direitos ou princípios constitucionais contrapostos, utilizando-se de um raciocínio ponderativo, guiado, especialmente, pelo princípio da proporcionalidade, tendo por fim identificar o direito definitivo. "São traçados, assim, os limites definitivos do direito, os quais, para essa concepção, são limites externos, já que resultam do 'recorte' do conteúdo inicialmente protegido do direito fundamental."20

Assim, voltando ao exemplo do artista que resolver pintar em um cruzamento movimentado, a teoria externa considera que o ato, em si, de pintar se insere no conteúdo prima facie da liberdade artística, sem olvidar, contudo, a perturbação do fluxo do tráfego e o perigo aos cidadãos causados por tal atividade. Tais razões, decorrentes do maior peso específico assumido no caso concreto pelo direito à integridade física de terceiros e por princípios "comunitários" como a rapidez do trânsito, justificam a restrição da liberdade artística e, via de conseqüência, a proibição concreta da pintura em exame. ${ }^{21}$ Percebe-se, portanto, que se atinge idêntico resultado - proibição concreta da pintura no cruzamento -, embora se percorra itinerários argumentativo e metodológico díspares.

Note-se, contudo, que a teoria externa parte de uma concepção de conteúdo de direito (prima facie) mais alargada do que a noção de conteúdo de direito (verdadeiro) esposada pela teoria interna, porquanto, efetivamente, insere naquele primeiro âmbito situaçōes concretas excluídas do último. Considerando, todavia, que a questão relativa a saber se uma determinada atividade está efetivamente protegida por direito fundamental não reconduz a respostas intermediárias entre o sim ou o não, a circunstância acima salientada não assumirá, necessariamente, divergência de resultados. Isto porque, apesar de a teoria externa considerar que uma forma de ação será jusfundamentalmente protegida se restar preenchido o âmbito de proteção prima facie do respectivo direito e não se verificar restrição, a teoria interna chegará a idêntica conclusão na hipótese de a situação concreta se amoldar ao conteúdo do direito demarcado por seus limites internos. Ora, se é fato que as restrições tendem a ser tanto mais amplas quanto mais abrangente for a definição do âmbito de proteção inicial, a teoria externa acaba por atingir conteúdo definitivo que tende a se aproximar do conteúdo verdadeiro preconizado pela teoria interna. ${ }^{22}$

A questão fulcral, portanto, reside em saber qual instrumental teórico confere maior objetividade e racionalidade à interpretação e aplicação dos direitos fundamentais, objetivos comuns àqueles que se debruçam sobre as potencialidades e as dificuldades inerentes à hermenêutica jurídica.

\footnotetext{
20 Ibidem.

2: Ibidem. p. 304-306.

22 A constatação é de W. BERG. Konkurrenzen shrankendivergenter Freiheitsrechte im Grundrechtsabschitt des Grudgesetzes, Berlin, 1986, Apud ALEXY, Robert. Op. cit., p. 299. Alexy, todavia, salienta que a amplitude do conceito de direito e das restriçōes é uma questāo normativa, voltando-se a sua concepção a uma teoria de construção do conteúdo dos direitos, que apenas residualmente apresenta implicações normativas.
} 
Várias razões conduzem à adoção da teoria externa. A primeira concerne à questão da estrutura das normas de direitos fundamentais. Neste ponto, cumpre salientar que a teoria interna, ao renunciar aos limites externos em favor dos internos, considera que a aferição da proteção jusfundamental de uma situação jurídica se dará mediante a sua adequação ao conteúdo do direito, em cuja operação hermenêutica exercerão notável relevo os elementos semântico, teleológico e sistemático. Todavia, a irrestrita recusa a restrições não expressamente autorizadas pela Constituição só seria factível se os direitos fundamentais fossem concebidos como regras ou comandos definitivos, aplicáveis segundo a lógica do "tudo ou nada", enfim, desde que não fossem descritos segundo a forma fluida que se costuma encontrar nas Declarações de Direitos, mas com a extensão e o detalhamento das normas de um Código. ${ }^{23}$

Revela-se, entretanto, largamente compartilhada no publicismo contemporâneo a perspectiva de que os catálogos constitucionais de direitos fundamentais possuem normas de densidades distintas, veiculando princípios e regras. A Constituição de 1988, por sua vez, claramente, contém direitos fundamentais veiculados sob a forma de princípios (igualdade, liberdade, segurança jurídica etc.) e sob a forma de regras (art. 5, LXIII, da CF/88: o preso será informado dos seus direitos, entre os quais o de permanecer calado [...], art. 5, LXIV: direito do preso à identificação dos responsáveis por sua prisão por seu interrogatório policial etc.).

Para além de não se amoldar aos catálogos de direitos fundamentais insertos nas Constituições contemporâneas, a teoria interna apresenta sérias deficiências hermenêuticas. Há de reconhecer-se, contudo, que a noção de que a aplicação de direitos fundamentais resumir-se-ia à adequação da situação em tela ao seu conteúdo predefinido constitucionalmente se revela, no plano teórico, em estrita consonância à rigidez e à supremacia da Constituição. Evita-se, assim, que o legislador e o julgador, com lastro em pautas fluidas como a ponderação e a proporcionalidade, e a pretexto de restringir os direitos fundamentais, venham efetivamente a malferir a sua essência. Todavia, a circunstância de os direitos fundamentais positivados sob a forma de princípios (i) possuírem baixa densidade normativa, (ii) freqüentemente colidirem sob a égide de Constituições compromissórias, e (iii) ostentarem uma dimensão moral que é objeto de sérias controvérsias nas sociedades contemporâneas etc. revela que há casos difíceis em que tal proposta hermenêutica de caráter conceitualista não se afigura suficiente para prover a racionalidade e a objetividade prometidas pela teoria interna à interpretação e aplicação dos direitos fundamentais.

Ao revés, é exatamente a partir da análise dos casos difíceis que se verifica que esta perspectiva conceitualista parte de um otimismo excessivo a respeito das potencialidades hermenêuticas do delineamento do conceito constitucionalmente estabelecido dos direitos fundamentais, acabando por promover uma excessiva simplificação da atividade relativa à sua interpretação e aplicação que, antes de

23 ALEXY, Robert. Op. cit., p. 130 ss. 
superar as dificuldades inerentes à indeterminação e à conflituosidade próprias dos princípios, oculta o problema. Tal circunstância, por paradoxal que soe, faz com que a teoria interna torne mais intenso o risco de decisionismo contra o qual se insurgira, porquanto abre mão de pautas argumentativas aptas a prover mínima racionalidade a tal atividade interpretativa - notadamente a ponderação, a proporcionalidade e a proteção do núcleo essencial.

A par disto, a teoria interna desonera o intérprete do intenso ônus argumentativo que faz parte do processo ponderativo, ${ }^{24}$ pois este não possuirá o dever de reproduzir o inexpugnável aspecto valorativo da decisão na sua fundamentaçāo, tornando-o insuscetível de controle intersubjetivo, isto é, da aferição da sua plausibilidade pela comunidade jurídica e pela sociedade em geral. Por outro lado, especificamente no que concerne à problemática dos conflitos entre direitos fundamentais, a solução alternativa de promover uma hierarquização apriorística e absoluta de uns direitos em detrimento de outros se coloca em frontal incompatibilidade com o princípio da unidade da Constituição, ${ }^{25}$ para além de desconsiderar a impossibilidade de serem resolvidos em tese, e mediante os clássicos critérios cronológico, hierárquico e da especialidade, os conflitos entre princípios constitucionais. ${ }^{26}$

Não é à toa que os adeptos da teoria interna opõem à teoria externa hipóteses em que a situação concreta em análise se afasta, nitidamente, da proteção jusfundamental. Com efeito, embora pareça estreme de dúvidas que pintar em cruzamentos movimentados, matar um ator no palco, promover sacrifícios humanos em cerimônias religiosas etc. não sejam objeto de proteção efetiva pelas liberdades artística e religiosa, respectivamente, ${ }^{27}$ não se afiguram tão cristalinas as diversas situações concretas em que os direitos à intimidade, à privacidade e à honra se opõem às liberdades de informação e de expressão. ${ }^{28}$ Que dirão as complexas questões afetas à relativização da coisa julgada, à aplicação dos direitos fundamentais às relações privadas, às políticas de açāo afirmativa, e, mais amplamente, à aferição do discrímen eleito pelo legislador nos casos relativos à aplicaçāo do princípio da igualdade? Parece claro que a busca de uma solução minimante consistente nestas hipóteses não prescinde do método da ponderação, dos princípios da proporcionalidade e da proteção do núcleo essencial, e, sobretudo, do especial ônus argumentativo neles implicado.

27 BARCELLOS, Ana Paula de. Ponderaçāo, racionalidade e atividade jurisdicional. Rio de Janeiro: Renovar, 2005. p. 70.

25 Ibidem. p. 41 ss.

26 Conferir, a propósito, a obra seminal de SARMENTO, Daniel. A ponderaçāo de interesses na Constituif̧ão de 1988. Rio de Janeiro: Lumen Juris, 2000. Sobre a solução de conflitos entre regras, ver BOBBIO. Norberto. Teoria do ordenamento jurídico. 10. ed. Brasília: Editora UnB, 1999.

27 PEREIRA, Jane Reis Gonçalves. Interpretaçāo constitucional e direitos fundamentais. p. 175.

28 Ver FARIAS, Edilsom Pereira de. Colisão de direitos: a honra, a intimidade, a vida privada versus a liberdade de expressão e informação. Porto Alegre: Sergio Antonio Fabris Editor, 2000. 
Já se salientou acima que a teoria externa atribui ao âmbito de proteção inicial do direito fundamental uma abrangência mais ampla do que a conferida ao conteúdo definitivo pela teoria interna, de maneira que o caso da pintura no cruzamento será considerado uma hipótese de restrição à liberdade artística mercê do maior peso específico de princípios comunitários, ao invés de concebê-lo como um simples caso de não-incidência do referido direito fundamental. Resta saber, contudo, se procede, no particular, a crítica de que a teoria externa promoveria um inflacionamento dos casos de direitos fundamentais, e notadamente das colisōes entre eles.

Neste ponto, cumpre repisar que não há vinculação entre maior proteçāo prima facie e proteção definitiva, pois a abrangência das restrições costuma ser diretamente proporcional à primeira. Ademais, com o perdão do truísmo, é bem de ver que a circunstância de uma situação concreta inserir-se no âmbito de proteção prima facie não significa que será objeto de proteção definitiva, mas tão-somente que a restrição deverá ser justificada mediante a demonstração de que outros princípios de igual hierarquia possuem, à luz do caso concreto, maior peso específico. A elucidação das razões que afastam o direito fundamental prima facie e o seu confronto com razões contrárias - algo que não é feito pela teoria interna - consiste em imperativo de racionalidade da argumentação jurídica. ${ }^{29}$ Cuida-se, portanto, de superar a deficiência de fundamentação da teoria interna, pois, conforme a salutar advertência de Carlos Bernal Pullido:

Pelo fato de falar-se em delimitação, não se suprime o risco de que intervenções legislativas possam vulnerar o conteúdo dos direitos fundamentais. [...] Chame-se de delimitação ou de restrição, o importante é ter claro que o legislador intervém nos direitos fundamentais e que toda intervenção legislativa deve estar sujeita a controle..$^{30.31}$

\footnotetext{
29 ALEXY, Robert. Op. cit., p. 305-306.

30 PULLIDO, Carlos Bernal. Op. cit.
}

${ }^{31}$ Nāo há sombra de dúvidas, contudo, de que o modo de proceder da teoria externa aumenta o número de casos suscetíveis de resoluçāo pela ponderaçāo. Alexy sustenta que tal assertiva nāo deve ser valorada negativamente, iniciando a sua "defesa" através da dissociaçāo entre casos reais e aparentes de direitos fundamentais. Esclarece, por sua vez, que um caso potencial de direito fundamental seria aquele em que, certamente, poderia se utilizar uma argumentação jusfundamental (i.e., ponderação), mas esta seria totalmente supérflua porque nāo há nenhuma dúvida no tocante à admissibilidade jusfundamental da solução jurídica ordinária. Já os casos reais seriam aqueles em que há fundada dúvida acerca da sua efetiva proteçāo jusfundamental, de maneira a impor-se, pelos motivos acima expostos, o método de argumentaçāo jusfundamental. Se se revelasse, singelamente, uma inequívoca e apriorística dissociaçāo entre as referidas hipóteses, aduz o Professor da Universidade de Kiel, se teria um argumento a favor da teoria interna, já que se verificaria uma superposiçāo da argumentação tradicional (i. e., conceptualização) pela jusfundamental.

Todavia, a total certeza ou incerteza da proteçāo jusfundamental, sobre a qual se erige a rígida dicotomia entre casos reais e aparentes de direitos fundamentais, deve ser substituída por uma "escala de certeza e incerteza", às quais se soma um aspecto subjetivo, na medida em que "diferentes pessoas atribuem a casos diferentes postos diferentes nesta escala de certeza e incerteza". Desta forma, em casos de incerteza, a solução mais razoável consiste em deduzir razões e contra-razōes a favor e contra 
Por todo o exposto, ante a prevalência dos princípios entre as normas de direito fundamental, em cujo delineamento concreto avulta um espaço de indeterminação, parece patente a insuficiência de aferições puramente conceituais e apriorísticas, e, inversamente, a relevância do emprego do método ponderativo e dos princípios da proporcionalidade e da proteção do núcleo essencial, com o fito de conferir mínima racionalidade à atividade judicial nesse particular.

\section{As modalidades de restrição aos direitos fundamentais}

Superado o estranhamento causado pela viabilidade jurídica de direitos concebidos como barreiras à atuação abusiva de órgãos estatais serem objeto de limitaçōes impostas pelo próprio Estado, cumpre indagar a respeito das espécies de restrições constitucionalmente legítimas.

A propósito, convém destacar que se revela corolário dos princípios da supremacia e da unidade da Constituição que as restriçōes aos direitos fundamentais e aos princípios constitucionais em geral decorram sempre de outra(s) norma(s) constitucional(is). Nada obstante, afigura-se útil distinguir as restriçōes (i) expressamente estatuídas pela Constituição, das (ii) expressamente autorizadas pela Constituição e das (iii) implicitamente autorizadas pela Constituição. ${ }^{32} \mathrm{~A}$ primeira espécie reúne as hipóteses em que a Constituição prevê cláusulas restritivas explícitas a direitos fundamentais, como, v. g., a limitação do direito de reunião pelas expressões pacificamente e sem armas; da liberdade de associação pela licitude dos fins e pela vedação ao caráter paramilitar; da vedação à pena de morte exceto em caso de guerra declarada etc. (incisos XVI, XVII, XLVI, do art. 5ª da Constituição de 1988).

a proteção jusfundamental, transcendendo já as fronteiras da conceptualizaçāo para a ponderação, isto é, da argumentação tradicional para a jusfundamental. Verificando-se, contudo, que há fortíssimas razōes em favor da proteçāo jusfundamental, não há óbice em afirmar a adequação do fato ao conteúdo do direito. Isto significa, ainda na esteira de Alexy, que a teoria interna só se revela útil em caso de ausência de dúvidas, circunstância que evidencia o seu caráter insatisfatório.

Ao contrário, a teoria externa tem a vantagem de tratar casos não duvidosos de direitos fundamentais como meros casos potenciais, em que a argumentação jusfundamental exerce posiçāo absolutamente supérflua em favor da argumentação tradicional. Já nos casos reais, em que a teoria interna, operacionalmente, se emudece, a teoria externa fornece uma argumentação jusfundamental substancial, orientada pelo princípio da proporcionalidade. V. ALEXY, Robert. Op. cit., p. 317.

32 PEREIRA, Jane Reis Gonçalves. Op. cit., p. 209 ss. Jane Pereira baseia-se na tradicional classificaçāo de Robert Alexy, que divide as restriçōes entre as "diretamente constitucionais" e as "indiretamente constitucionais", com a vantagem de, mantidas as premissas do jusfilósofo alemão, subdividir as últimas em "expressamente autorizadas pela Constituiçāo" e "implicitamente autorizadas pela Constituição". Desta feita, logra-se manter as premissas fundamentais à classificação em tela (especialmente o fundamento constitucional - ainda que mediato - de toda e qualquer restrição), sem incorrer no inconveniente de albergar no mesmo item hipóteses sensivelmente distintas, quais sejam, as restriçōes expressamente estatuídas, sob a forma de regras, na Constituiçāo, das que decorrem de conflitos entre princípios constitucionais. V. ALEXY, Robert. Op. cit., p. 276 ss. 
Já as restrições expressamente autorizadas pela Constituição são implementadas por atos infraconstitucionais, com lastro em norma constitucional que, explicitamente, confere tal competência aos órgãos estatais respectivos. Note-se que, na vertente em hipótese, a norma constitucional não estatui de per se a restriçāo, mas tão-somente autoriza que ela seja implementada. Inserem-se nesta modalidade, por exemplo, os casos em que o constituinte reservou ao Judiciário a realização da alvitrada limitação - cite-se, entre as hipóteses de reservas de jurisdição, a possibilidade de o Judiciário afastar a inviolabilidade do domicílio (art. 5", XI, CRFB/1988) -, bem como estabeleceu reservas legais, assim compreendidas as hipóteses em que a viabilidade de restrição se sujeita à edição de lei formal.

As reservas legais, por sua vez, subdividem-se em simples e qualificadas: nas primeiras o constituinte limita-se a exigir lei formal, mediante o emprego de expressões como na forma da lei, nos termos da lei, lei estabelecerá etc.; nas últimas, a norma constitucional em tela não se restringe a prever a autorização, mas também promove a predeterminação de algum aspecto da restrição a ser implementada.

São exemplos de reservas legais simples os incisos VII e XV do art. 5 da $\mathrm{CRFB} / 88$, nos quais se asseguram, "nos termos da lei", a prestação de assistência religiosa nas entidades civis e militares e a livre locomoção no território nacional em tempos de paz, respectivamente. Os incisos XIII e LX do art. $5^{\circ}$ da CRFB/88, por sua vez, veiculam típicos exemplos de reserva legal qualificada, na medida em que não apenas prevêem a possibilidade de a lei restringir os direitos ao livre exercício de qualquer trabalho e à publicidade dos atos processuais, como também predeterminam a finalidade da limitação - aferição de qualificação profissional e defesa da intimidade e do interesse social, respectivamente.

Incluem-se também entre as restrições expressamente autorizadas pela Constituição de 1988 as hipóteses de defesa do Estado e das instituiçōes democráticas (Estado de Defesa e Estado de Sítio), nas quais se autoriza, mediante a concreção das hipóteses excepcionais e das condições descritas nos arts. 136, 137 e 138 da Constituição de 1988, que o Presidente da República edite decreto - sujeito a controle do Congresso Nacional - que restrinja os direitos arrolados nos arts. 136 e 139 da CRFB/1988.

Ademais, viu-se no item 2 que uma hermenêutica constitucional metodologicamente conseqüente tende a reconhecer a inevitabilidade de os princípios constitucionais, sobretudo no âmbito de Constituiçōes compromissórias, entrarem em conflito, circunstância que compele o legislador e o juiz a realizarem restrições recíprocas entre os princípios conflitantes (teoria externa). É precisamente a solução de conflitos entre princípios constitucionais a hipótese por excelência de restriçōes implicitamente autorizadas pela Constituição, pois, neste caso, haja ou não autorização constitucional explícita para a restrição, esta se consubstancia em premissa inafastável da resolução do conflito. 
Por outro lado, a associação do princípio da reserva de lei restritiva com os princípios supra-citados implica não apenas que a restrição se dê por lei formal, mas exigências sobre o conteúdo da lei restritiva. A propósito, o princípio da segurança jurídica, ao preconizar "um ideal de estabilidade, confiabilidade, previsibilidade, e mensurabilidade na atuação do poder público", ${ }^{42}$ evidentemente impõe que as normas restritivas de direito fundamental apresentem um nível mínimo de clareza e determinação, porquanto esta exigência substantiva viabiliza o conhecimento dos propósitos do legislador e das conseqüências jurídicas da atuação em conformidade ou em desconformidade à norma. Canotilho assinala que a norma em tela deve ter densidade suficiente para (i) alicerçar "posições juridicamente protegidas" dos cidadãos, (ii) constituir uma "norma de actuação" para a Administração Pública, (iii) possibilitar, como norma de controle, a fiscalização da legalidade e da defesa dos direitos e interesses dos cidadãos. ${ }^{43}$ Os dois últimos aspectos evidenciam que uma tal exigência de determinabilidade mínima da lei restritiva se vincula não apenas à previsibilidade da conduta imposta, vedada ou permitida pela ordem jurídica (segurança jurídica), mas igualmente à definição de parâmetros inteligíveis de controle do Poder Executivo, associandose à tradicional função legitimadora da atividade administrativa exercida pelo princípio da legalidade. ${ }^{44}$

Além disto, do princípio da igualdade decorre que as normas restritivas de direitos fundamentais devem apresentar conteúdo genérico e abstrato, e, inversamente, a vedação da edição de leis e emendas de natureza individual e concreta que promovam distinções casuísticas e arbitrárias entre os seus destinatários. Celso Antônio Bandeira de Mello, em seminal estudo, desenvolve com maior precisão o conteúdo jurídico do princípio da igualdade, aduzindo que "as discriminaçōes são recebidas como compatíveis com a cláusula igualitária apenas e tão-somente quando existe um vínculo de correlação lógica entre a peculiaridade diferencial acolhida por residente no objeto, e a desigualdade de tratamento em função dela conferida, desde que tal correlação nāo seja incompatível com interesses prestigiados na Constituição". ${ }^{45}$ A aferição do vínculo de pertinência lógica entre o discrímen eleito pelo legislador e o tratamento legal diferenciado em função dele promovido não prescinde, antes pressupõe, o emprego do princípio da proporcionalidade.

A proporcionalidade, por sua vez, segundo a sua clássica formulação no constitucionalismo germânico, divide-se em três subprincípios: (i) adequação: aptidão do meio eleito em fomentar a promoção da finalidade pretendida; (ii) necessidade:

\footnotetext{
t2 ÁVILA, Humberto Bergman. Sistema constitucional tributário. Sāo Paulo: Editora Saraiva, 2004. p. 295.

43 CANOTILHO, José Joaquim Gomes. Direito constitucional e teoria da constituiçāo. Coimbra: Almedina, 1999. p. 253.

44 ANDRADE, José Carlos Vieira de. Os direitos fundamentais na Constituição portuguesa de 1976. 2. ed., Coimbra: Almedina., 2001. p. 336 ss.

t5 MELLO, Celso Antônio Bandeira de. Conteúdo juridico do princípio da igualdade. Sāo Paulo: Malheiros Editores, s/d. p. 17.
} 
Por fim, convém destacar que as restrições aos direitos fundamentais podem se dar nos planos legislativo e aplicativo. Refere-se a restrições legislativas em alusão às hipóteses em que é editada lei geral e abstrata com o fito de concretizar a norma constitucional, conformando, reduzindo, ou ampliando o conteúdo prima facie do direito fundamental respectivo. Através deste delineamento, estabelece-se o âmbito de proteção legal de caráter definitivo do direito fundamental em questão. Já as restrições aplicativas não se operam em um plano geral e abstrato, mas concreto e individual. Situando-se no plano aplicativo, tais restrições consistem no afastamento, no âmbito de situação específica, da posição jurídica individual respectiva, sem que se verifique prejuízo ao conteúdo objetivo do direito fundamental estabelecido na Constituição e nas leis. ${ }^{33}$ À guisa de ilustração, Jorge Reis Novais salienta que, enquanto norma que regule a possibilidade de órgãos públicos desapropriarem propriedades particulares consiste em restrição legislativa ao direito de propriedade, o ato de desapropriação se consubstanciará em restrição aplicativa.

\section{Os limites dos limites}

No âmbito de um Estado de Direito, a possibilidade de legisladores e juízes promoverem, concretamente, restrições aos direitos fundamentais pressupōe que esta atividade se revele, igualmente, limitada. Daí se falar em limites dos limites (Schranken-Schranken) aos direitos fundamentais, expressão clássica no constitucionalismo germânico cunhada por Karl August Betterman, em célebre conferência proferida na sociedade jurídica de Berlim em $1964 .{ }^{34}$ Segundo a profícua síntese de Gilmar Ferreira Mendes, devem ser considerados limites dos limites: (i) o princípio da clareza e da determinação das normas restritivas, (ii) a proibição de restriçōes casuísticas, (iii) o princípio da proporcionalidade, (iv) e o princípio da proteção do núcleo essencial..$^{35} \mathrm{~A}$ este rol cumpre acrescentar o princípio da "reserva de lei restritiva". ${ }^{36}$

Neste ponto, convém destacar que é assente a noção de que as restrições legislativas (gerais e abstratas) ${ }^{37}$ aos direitos fundamentais, sejam elas expressa ou implicitamente autorizadas pela Constituição, estão sujeitas à reserva de lei

\footnotetext{
33 PEREIRA, Jane Reis Gonçalves. Op. cit., p. 205; NOVAIS, Jorge Reis. As restriçōes aos direitos fundamentais não expressamente autorizadas pela Constituição. Coimbra: Coimbra Editora, 2003, p. 193 ss. Cumpre esclarecer que o autor português utiliza as expressōes restriçōes em sentido estrito e intervençōes restritivas para designar o que Jane houve por bem chamar de restrições legislativa e aplicativa, em nomenclatura que se adotou por seu maior potencial esclarecedor.

34 PULLIDO, Carlos Bernal. Op. cit., p. 518.

35 MENDES, Gilmar Ferreira. Direitos fundamentais e controle de constitucionalidade. São Paulo: Celso Bastos Editor, 1999. p. 38 ss.

36 QUEIROZ, Cristina. Direitos fundamentais: teoria geral. Coimbra: Coimbra Editora, 2003. p. 2002.

3. V. seção 3.
} 
Com efeito, os subprincípios da adequação e da necessidade se destinam a determinar, à luz do caso concreto, a otimização possível dentro dos limites fáticos a que estão sujeitos os princípios, visto que identificam o grau de fomento e restrição dos princípios em colisão. Já a proporcionalidade em sentido estrito diz com as possibilidades jurídicas dos princípios, na medida em que consiste em um mandamento de ponderação do princípio em tela com o princípio que com ele colide, com o escopo de aferir a eventual superação das vantagens decorrentes da aplicaçāo do primeiro sobre as desvantagens do afastamento do segundo. ${ }^{56}$ É mister notar, contudo, que a inevitabilidade do princípio da proporcionalidade no âmbito de ordem jurídica que preveja princípios nāo exclui a busca de sua fundamentação no direito constitucional positivo, a qual, ao revés, consiste em bem-vindo reforço à sua legitimação jusfundamental. ${ }^{57}$

A notável relevância do princípio da proporcionalidade no panorama atual do direito brasileiro é comprovada pela profusão de obras acadêmicas ${ }^{58}$ e pela sua crescente utilização pelos Tribunais pátrios. Embora exames típicos de proporcionalidade e razoabilidade de atos do poder público tenham sido empregados pelo Supremo Tribunal Federal antes da Constituição de 1988, somente após a edição da novel ordem constitucional o Excelso Pretório passou a empregar, expressa e crescentemente, os princípios da proporcionalidade e da razoabilidade como parâmetros destinados a aferir a constitucionalidade dos atos do poder público, sobretudo os restritivos de direitos fundamentais. ${ }^{59}$

56 ALEXY, Robert. Op. cit, p. 110 ss.

5) Ibidem. p. 115.

58 Além das obras citadas nas antecedentes notas, cite-se, para fins meramente ilustrativos, BUECHELE, Paulo Armínio Tavares. O principio da proporcionalidade e sua interpretação da Constituição. Rio de Janeiro: Renovar, 1999; SARMENTO, Daniel. Ponderação de interesses na Constituição Federal. Rio de Janeiro: Lumen Juris, 2002; STEINMETZ, Wilson Antônio. Colisão de direitos fundamentais e princípio da proporcionalidade. Porto Alegre: Livraria do Advogado, 2001; STUMM, Raquel Denize. O princípio da proporcionalidade no direito constitucional brasileiro. Porto Alegre: Livraria do Advogado, 1995; TORRES, Ricardo Lobo. A legitimação dos direitos humanos e os princípios da ponderação e da razoabilidade. In: TORRES, Ricardo Lobo. (Org.). Legitimaçāo dos direitos humanos. Rio de Janeiro: Renovar, 2002. p. 397-449.

59 Para um profícuo recenseamento da jurisprudência do Supremo Tribunal Federal sobre a proporcionalidade, conferir MENDES, Gilmar Ferreira. Op. cit., 1999, p. 71-87. O leading case a respeito da explícita utilização do princípio da proporcionalidade, como se sabe, foi a $\mathrm{ADIn} \mathrm{n}^{\underline{0}} 885$, na qual se declarou a inconstitucionalidade, entre outros, do caput do art. $1^{\circ}$ da Lei $n^{\circ} 10.428$, de 14.1.1993, do Estado do Paraná, assim vazado: "art. $1^{\circ}$ É obrigatória a pesagem, pelos estabelecimentos que comercializarem - GLP - Gás Liquefeito de Petróleo, à vista do consumidor, por ocasiāo da venda de cada botijāo ou cilindro entregue e também recolhido, quando procedida à substituição". O Supremo, em voto condutor do Ministro Pertence, salientou que os esclarecimentos do INMETRO: "servem, de um lado, como proficientemente explorado na petiçāo, nāo só para lastrear o questionamento da proporcionalidade ou da razoabilidade da disciplina legal impugnada, mas também para indicar a conveniência de sustar - ao menos, provisoriamente - as inovaçōes por elas impostas, as quais, onerosas e de duvidosos efeitos úteis, acarretariam danos de incerta reparaçāo para a economia do setor, na hipótese - que não é de afastar - de que se venha ao final a declarar a inconstitucionalidade da lei". V. $A D I n n^{\circ} 885$, Rel. Min. Sepúlveda Pertence, $D J 1^{\circ} .10 .1993$. Para uma contundente crítica ao referido acórdão, ver SILVA. Virgílio Afonso da. Op. cit. 
aferição da impossibilidade de o objetivo pretendido ser promovido, com a mesma intensidade, por intermédio de outro ato que limite, em menor medida, o direito fundamental atingido; (iii) proporcionalidade em sentido estrito: sopesamento entre a intensidade da restrição ao direito fundamental atingido e a importância da realização do direito fundamental que com ele colide e que fundamenta a adoção da medida restritiva. ${ }^{46}$

Preliminarmente, cumpre salientar a existência de sérias controvérsias no direito brasileiro a respeito da fungibilidade entre os princípios da proporcionalidade e da razoabilidade. Nada obstante, há certo consenso a respeito de ambos os princípios atuarem como parâmetros destinados a aferir a justiça substancial, a racionalidade e o comedimento dos atos do poder público, bem como possuírem origens distintas, na medida em que a razoabilidade se erigiu no direito norte-americano a partir da versão substantiva da cláusula do due process of law, constante da quinta e da décima quarta emendas à Constituição de $1787,{ }^{47}$ enquanto a proporcionalidade foi transplantada do direito administrativo europeu para consubstanciar-se, originariamente na Alemanha, no critério por excelência da aferição da constitucionalidade das leis restritivas aos direitos fundamentais, mediante uma exegese construtiva da cláusula do Estado de Direito e da estrutura dos direitos fundamentais. ${ }^{48}$

No que toca especificamente à identidade do conteúdo jurídico dos princípios da proporcionalidade e da razoabilidade, há aceso embate no constitucionalismo brasileiro. A intercambialidade entre os referidos princípios é afirmada por iterativa jurisprudência do Supremo Tribunal Federal, e por constitucionalistas de escol, como, p. ex., Luís Roberto Barroso e Gilmar Ferreira Mendes, ${ }^{49}$ os quais se utilizam do maior desenvolvimento analítico obtido pelo constitucionalismo germânico para considerar que os referidos princípios se subdividem, consoante acima assinalado, em adequação, necessidade e proporcionalidade em sentido estrito.

Já autores como Humberto Ávila, Jane Reis e Luís Virgílio Afonso da Silva sustentam que proporcionalidade e razoabilidade não se confundem. Humberto Ávila, em concepção pioneira sobre a vertente questão, salienta que a proporcionalidade se consubstanciaria em "postulado estruturador da aplicaçāo de princípios que concretamente se imbricam em torno de uma relação de causalidade entre um meio e um fim", subdividindo-se em adequação, necessidade e proporcionalidade em sentido estrito. Já a razoabilidade não estaria vinculada às relações causais entre meio e fim, mas consistiria em estrutura de aplicação de princípios

46 SILVA, Luís Virgílio Afonso da. O proporcional e o razoável. Revista dos Tribunais, 798, p. 23-50, abr. $/ 2002$.

4: NOWAK, John E.; ROTUNDA, Ronald D. Constitutional law. St. Paul: Thomson West, 2004. p. 398 ss.

48 SHOELLER, Heinrich. O princípio da proporcionalidade no direito constitucional e administrativo da Alemanha. Interesse Público, v. 1, ño 2, p. 93, 1999.

49 BARROSO, Luís Roberto. Interpretação e aplicação da Constituição. p. 209 ss; MENDES, Gilmar Ferreira. Op. cit., p. 31 ss. 
Por fim, cite-se o princípio da salvaguarda do núcleo essencial, o qual, embora previsto expressamente, $v$. g., na Lei Fundamental de Bonn (art. 19, inc. 2), na Constituição portuguesa de 1976 (art. 18, 3) e na Constituição espanhola de 1978 (art. 53.1), não foi mencionado pelo constituinte brasileiro de 1988. O vetor exegético em apreço preconiza que, muito embora seja da essência dos princípios jurídicos a suscetibilidade de sofrerem restrições na hipótese de colisão com outros princípios, eles possuem um núcleo inexpugnável, é dizer, um âmbito de proteção mínimo dentro do qual nenhuma intervenção normativa se afigura legítima. Não é difícil entrever cuidar-se de reação à concepção prevalecente no Estado de Direito legalista, segundo a qual o legislador teria, na prática, uma liberdade amplíssima para a conformação dos direitos fundamentais. ${ }^{60}$ Efetivamente, a salvaguarda do núcleo essencial, ao afirmar que os direitos fundamentais têm um mínimo de conteúdo garantido constitucionalmente, visa a reforçar a vinculação material do legislador ao seu teor, evitando o risco, verificado, p. ex., sob a égide da Constituição de Weimar, de erosão dos direitos fundamentais por intervenções legislativas abusivas. ${ }^{61} \mathrm{O}$ objeto e a natureza da proteção promovida pelo princípio da salvaguarda do núcleo essencial é, contudo, alvo de sérias controvérsias.

Quanto ao primeiro aspecto, opõem-se as teorias objetiva e subjetiva. A primeira nasce da necessidade de conceber-se uma explicação teórica para uma per-

\footnotetext{
6i O modelo de Estado de Direito Legalista, prevalecente na Europa Continental das Revoluções Burguesas ao segundo pós-guerra, caracteriza-se, fundamentalmente, pela prirnazia do Legislativo dentre os departamentos estatais de soberania. A propósito, a influência exercida pelo conceito moderno-iluminista de lei sobre este arranjo institucional, que vislumbrava a lei como expressāo inelutável dos imperativos da razão e da vontade do povo, acabava por reconduzir as manifestações estatais à criação e à aplicaçāo do direito, e, conseqüentemente, à dicotomia funçāo legislativa versus função executiva lato sensu (que abrangia as funções judicial e executiva stricto sensu). Desta hierarquização funcional decorria correlata hierarquização entre os órgãos estatais, de maneira a conceber-se a supremacia da lei e do Parlamento em relação aos poderes Executivo e Judiciário e aos seus respectivos atos. Esta relação superior-subalterno entre os órgāos do Estado implicará, naturalmente, um modelo político-institucional cuja nota distintiva é o monismo do Poder Legislativo, na medida em que todo o poder político efetivo será concentrado no Parlamento. Das diversas conseqüências do que se expôs, uma é de especial importância para a confirmação da tese de que, na prática, o Legislador tinha uma liberdade quase que absoluta na conformação dos direitos fundamentais, a saber: se o Legislador se achava livre de constrangimentos efetivos, na medida em que se atribui a seus atos a natureza de lídima manifestação da soberania, verifica-se uma estranha "soberania de poder constituido". De fato, sendo o Legislador legibus solutus, este órgão estatal se torna autor do seu próprio poder, podendo alterar o direito positivo (inclusive a Constituição) quando e como bem entender, de modo a emitir, incessantemente, uma vontade ilimitada capaz de redefinir a forma de governo, as instituiçōes políticas e o conteúdo dos direitos fundamentais. Desta forma, esta curiosa convolação dos "representantes da nação soberana" em "representantes soberanos da naçāo" gera uma confusāo entre os poderes constituinte e constituídos, e, por conseguinte, a própria inviabilidade do conceito de poder constituinte, o qual, ao menos em sua tradicional formulação de matriz norte-americana, parece vincular-se à superioridade $\mathrm{e}$ à pré-estatalidade da vontade do povo sobre a dos poderes constituídos, e, portanto, à noçāo de rigidez constitucional. Ver FIORAVANTI, Maurizio. Los derechos fundamentales - apuntes de la historia de las constituciones. 4. ed. Madrid: Editorial Trotta, 2003; VEGA, Pedro de. La reforma constitucional y la problematica del poder constituyente. 5. reimpresión, Madrid: Tecnos, 2000; PIÇARRA, Nuno. A separaçāo de poderes como doutrina e princípio constitucional. Coimbra: Coimbra Editora, 1989.
}

6) MENDES, Gilmar Ferreira. Os limites dos limites. In: MENDES, Gilmar Ferreira et al. Hermenêutica constitucional e direitos fundamentais. Brasília: Brasília Jurídica, 2000. p. 241-314. 
formal. Assim, é exatamente nas hipóteses em que o constituinte não permitiu expressamente a restrição que a exigência de lei formal, ainda que não prevista em seu texto, mais se afigura necessária, pela evidente imprescindibilidade de maior rigor no seu controle. ${ }^{38}$ Tal circunstância evidencia a pertinência de adotar-se o princípio da reserva de lei restritiva no Brasil, ainda que a Constituição de 1988 não tenha seguido o exemplo da Lei Fundamental de Bonn de 1949 e da Constituição portuguesa de 1976, que o prevê expressamente. De qualquer sorte, tal princípio pode ser inferido da interpretação sistemática de uma série de dispositivos constitucionais, como os arts. $5^{\circ}$, II, 37, caput, 62 , II, e $68, \$ 1^{1}$, II, da CRFB/1988. ${ }^{39}$

Se lei formal pode promover restrição a direito fundamental, com muito mais razão emenda constitucional poderá fazê-lo. A bem da verdade, o próprio constituinte, ao vedar apenas as emendas constitucionais "tendentes a abolir" as cláusulas pétreas, deixou claro que não são todas as restrições veiculadas por emendas que se afiguram constitucionalmente ilegítimas, mas apenas as que limitem a respectiva cláusula para além de determinados limites, a partir dos quais se verifica o caráter tendencialmente aniquilador do direito "restringido" pela emenda respectiva. ${ }^{40}$ Urge, portanto, densificar os referidos limites.

Neste particular, avulta a importância de um parâmetro de ponderação, a saber: no controle da constitucionalidade de emendas constitucionais restritivas de direitos fundamentais, o Judiciário deve adotar uma postura mais intensa de auto-restriçāo judicial do que quando a restrição provier de lei. A razão é simples: tendo em vista o maior rigor procedimental atinente ao processo de aprovação de emendas (iniciativa qualificada, dois turnos, e, especialmente, quórum de $3 / 5$ (três-quintos)) quando comparado ao processo legislativo ordinário (um turno de votação e quórum de maioria simples), soa evidente que a superação do primeiro revela um consenso mais forte no âmbito do Congresso Nacional. Ora, se o Judiciário, ao exercer o controle de constitucionalidade dos atos do Parlamento, notadamente quando adotar uma postura ativista na aplicação de norma constitucional de natureza principiológica (i. e., os direitos fundamentais), tende a comprimir o espectro de atribuições do Parlamento em favor das suas competências - circunstância que, no bojo das democracias representativas, apresenta uma dificuldade contramajoritária ${ }^{41}$-, parece natural que adote postura tão mais acanhada quanto mais sólido for o consenso obtido no Congresso Nacional.

\footnotetext{
$38 \quad$ NOVAIS, Jorge Reis. Op. cit., p. 825.

39 PEREIRA, Jane Reis Gonçalves. Op. cit., p. 305.

40 Nada obstante a relevância do elemento literal, tem-se que o esforço despendido no item dois para a demonstraçāo da inevitabilidade de os legisladores ordinário e constituinte-reformador imprimirem efetivas restrições aos direitos fundamentais revela-se fundamental para a confirmação do sentido que se depreende da literalidade do dispositivo interpretado.

${ }^{41}$ A expressão foi consagrada na clássica obra de BICKEL, Alexander M. The least dangerous branch: the Supreme Court at the bar of politics. 2. ed. New Haven: Yale University Press, 1986. Na doutrina nacional, ver o célebre livro de BARROSO, Luís Roberto. Interpretaçāo e aplicaçāo da Constituição: fundamentos de uma dogmática constitucional transformadora. Rio de Janeiro: Saraiva, 1999. p. 163.
} 
e de regras, utilizada em diferentes contextos. Em esforço de reconstrução analítica das decisões dos Tribunais Superiores, Humberto Ávila assim sistematiza as principais acepçōes emprestadas à razoabilidade: (i) razoabilidade como eqüidade: harmonização da norma geral com o caso individual; (ii) razoabilidade como congruência: harmonização das normas com as condiçōes externas de aplicação; (iii) razoabilidade como equivalência: equivalência entre a medida adotada e o critério que a dimensiona. ${ }^{50}$

Há também forte divergência a respeito do fundamento constitucional da proporcionalidade, vislumbrando-se cinco teses principais acerca da sua sedes materiae: (i) a primeira considera, na linha do constitucionalismo norte-americano, a cláusula do devido processo legal (art. $5^{\circ}$, LIV, da CRFB/1988), em sua versão substantiva; ${ }^{51}$ (ii) a segunda, com lastro na jurisprudência do Tribunal Constitucional alemão, identifica a cláusula do Estado de Direito (art. $1^{\circ}$ ) $;^{52}$ (iii) a terceira arrola uma série de dispositivos legais, dentre os quais o art. $1^{\circ}$, caput, I, II, e III, art. $5^{\circ}$, II, XXXIV, a, XXXV, LXII, LXVIII, LXIX; ${ }^{53}$ (iv) a quarta indica a cláusula contida no art. $5^{\circ}, \$ 2^{\circ}$, a qual abre o catálogo de direitos fundamentais a direitos decorrentes do regime e dos princípios por ela adotados e previstos em tratados internacionais de que o Brasil seja parte; ${ }^{54}$ (v) e, finalmente, coloca-se corrente que considera a proporcionalidade corolário lógico da positivação de princípios, segundo o sentido que lhe é conferido por Alexy. ${ }^{55}$

Parece que a proporcionalidade e os princípios posicionam-se, efetivamente, em relaçāo de mútua implicaçāo, desde que se parta do conceito que Alexy empresta aos últimos, ou seja, desde que os princípios jurídicos sejam vistos como mandados de otimização, porquanto aplicáveis, na maior medida possível, dentro das suas possibilidades fáticas e jurídicas.

\footnotetext{
50 ÁVILA, Humberto Bergman. A distinção entre princípios e regras e a redefiniçāo do dever de proporcionalidade. Revista do Direito Administrativo, 215 (1999). p. 102 ss. Conferir também SILVA, Luís Virgílio Afonso da. O proporcional e o razoável. Revista dos Tribunais, 798, abril/2002. e PEREIRA, Jane reis Gonçalves. Op. cit., p. 310 ss.

5t Neste sentido, posiciona-se o próprio Supremo Tribunal Federal, conforme o recenseamento realizado por Gilmar Ferreira Mendes acerca da jurisprudência produzida, neste particular, pelo Excelso Pretório, cf. MENDES. Op. cit., p. 87, e Adin $\mathrm{n}^{\mathrm{N}}$ 1407-2, DJU 15.3.1996; e, em sede doutrinária, BARROSO. Op. cit., p. 227.

52 BverfGE 90, 145 (173); BARROS, Suzana de Toledo. O princípio da proporcionalidade e o controle de constitucionalidade das leis restritivas de direitos fundamentais. Brasília: Brasília Jurídica, 2003. p. 93 ss; SAMPAIO, Patrícia Regina Pinheiro; SOUZA, Carlos Affonso Pereira de. O princípio da proporcionalidade e o princípio da razoabilidade: uma abordagem constitucional. Revista Forense, v. 349, p. 29-41, 1999.

53 BONAVIDES, Paulo. Op. cit., p. 434 ss.

54 BONAVIDES, Paulo. Op. cit.; GUERRA FILHO, Willis Santiago. Princípio da proporcionalidade e teoria do direito. In: GRAU, Eros Roberto; GUERRA FILHO, Willis Santiago (Org.). Direito constitucional: estudos em homenagem a Paulo Bonavides. São Paulo: Malheiros, 2001. p. 268-283.

55 SILVA. Op. cit., p. 43-44; ÁVILA, Humberto Bergman. A distinção entre princípios e regras e a redefinição do dever da proporcionalidade, Revista de Direito Administrativo, 215 (1999): 151-179; ALEXY, Robert. Op. cit., p. 111 ss.
} 
plexidade, qual seja, a suposta inevitabilidade de, em situações-limite, negar-se tutela jurídica a situações jurídicas subjetivas que fazem parte da essência do direito fundamental em questão. O exemplo clássico é o da prisão perpétua, no qual o cerne da liberdade de ir e vir do condenado parece, realmente, restar aniquilado. A saída encontrada foi considerar-se que o princípio da salvaguarda do núcleo essencial não se refere à liberdade concreta desta ou daquela pessoa (direito subjetivo), mas ao direito fundamental enquanto instituição objetiva do sistema jurídico, de forma a tutelar-se apenas a sua permanência abstrata no direito positivo. ${ }^{62}$

Como era de se esperar, esta tese foi duramente criticada, sob o argumento principal de retirar toda a serventia prática da garantia do núcleo essencial, já que a simples tutela do direito enquanto instituição objetiva não fornece óbices reais a que o governo procedesse à sistemática violação dos direitos fundamentais, porquanto poderia suprimir amplamente os direitos subjetivos deles decorrentes. $\mathrm{Na}$ verdade, a garantia da permanência abstrata do direito protegeria apenas os cidadãos contra a imposição aberta de um Estado totalitário, não impedindo violações concretas perpetradas no bojo de um Estado pretensamente democrático. ${ }^{63}$

Com lastro em argumentos deste jaez, erige-se a teoria subjetiva que, por seu turno, sustenta que o princípio da salvaguarda do núcleo essencial se destina a proteger posiçōes jusfundamentais concretas, é dizer, os direitos fundamentais enquanto direitos subjetivos. Embora os conflitos extremos em que um dos direitos fundamentais tenha que ser afastado sejam mais facilmente solucionáveis dentro do marco da teoria objetiva, anota Alexy que a circunstância de os direitos fundamentais ostentarem uma inequívoca dimensão subjetiva milita em favor da adoção da teoria subjetiva, mesmo que ao lado da teoria objetiva. ${ }^{64}$ De fato, se a teoria subjetiva tem a vantagem de não olvidar a proteção da dimensão subjetiva dos direitos fundamentais, ela, em comparação com a teoria objetiva, apresenta a desvantagem de não deixar suficientemente claro que as regulaçōes objetivas de direitos fundamentais também devem restar protegidas, para além de trazer dificuldades de justificação de casos excepcionais em que o afastamento de um dos direitos fundamentais reduz a quase nada o seu âmbito de proteção. ${ }^{65}$

Neste quadro, avulta a importância da advertência de Konrad Hesse, para quem nenhuma das teorias fornece, isoladamente, resposta satisfatória para a proteçāo dos direitos fundamentais, porquanto estes possuem dimensões subjetiva e objetiva que não são mutuamente excludentes, mas que, ao revés, compōem a estrutura dos direitos fundamentais. ${ }^{66} \mathrm{Com}$ efeito, se os direitos fundamentais são,

62 CIANCIARDO, Juan. Op. cit., p. 253/254. Adotam, por exemplo, a teoria objetiva, ANDRADE, José Carlos Vieira de. Op. cit, p. 296 ss; PEREZ-LUÑO, Antonio Henrique. Los derechos fundamentales. Madrid: Tecnos, 1998. p. 78.

63 NOVAIS, Jorge Reis. Op. cit., p. 785.

64 ALEXY, Robert. Op. cit., p. 288.

65 CIANCIARDO, Juan. Op. cit., p. 256.

ó HESSE, Konrad. Elementos de direito constitucional da República Federal da Alemanha. Porto Alegre: Sergio Antonio Fabris Editor, 1999. p. 268. 
concomitantemente, direitos subjetivos indispensáveis ao desenvolvimento pessoal dos indivíduos e instituições que suportam axiologicamente todo o ordenamento jurídico, a garantia do núcleo essencial deve abranger ambas as dimensões, protegendo o direito respectivo de ingerências promovidas tanto no plano da regulação objetiva quanto na determinação de uma posição jusfundamental concreta. ${ }^{67}$

Note-se, contudo, que nenhuma das referidas teorias fornece resposta sobre a questāo fundamental atinente a saber o ponto a partir do qual uma restrição legislativa a direito fundamental, quer no plano subjetivo, quer no plano objetivo, atente contra o seu núcleo essencial. No que toca especificamente à definição do alcance da salvaguarda do núcleo essencial como limite dos limites, salienta Jane Pereira que

os autores dividem-se entre aqueles que consideram que o conteúdo essencial traduz apenas a necessidade de justificação de eventual restrição aos direitos (teoria relativa), e os que entendem que este constitui uma garantia absoluta, não podendo, em hipótese alguma, ser afetado (teoria absoluta). ${ }^{68}$

A teoria relativa não considera possível determinar, aprioristicamente, o conteúdo essencial dos direitos fundamentais, na medida em que este só seria identificado após processo ponderativo guiado pelo princípio da proporcionalidade. Sendo o núcleo essencial "aquilo que sobra após a ponderação", ${ }^{69}$ tal garantia se confunde com a proporcionalidade, nada acrescentando à limitação da restringibilidade dos direitos fundamentais. Revela-se também corolário do exposto a possibilidade de um direito fundamental restar completamente comprimido após a ponderaçāo, desde que o referido juízo haja se pautado pela proporcionalidade.$^{70} \mathrm{~A}$ conclusão que se impõe é que o princípio da salvaguarda do núcleo essencial assume apenas as funçōes de reafirmar a necessidade de justificação de restriçōes aos direitos fundamentais e de reforçar o uso do princípio da proporcionalidade. ${ }^{71}$

A teoria absoluta, inversamente, compreende o núcleo essencial como "um núcleo fixo que independe de ponderação". ${ }^{72}$ Assim, a teoria absoluta se afasta da perspectiva meramente relacional da teoria relativa, orientando-se para a busca de um âmbito que se consubstancie em um último reduto de proteção, absolutamente insuperável. Baseia-se, portanto, em uma visão espacial que compreende o âmbito de proteção dos direitos fundamentais como composto de dois círculos concêntricos, concebidos como "camadas de resistência diversificada", visto que, enquanto o círculo de maior raio consiste em prerrogativas não essenciais que to-

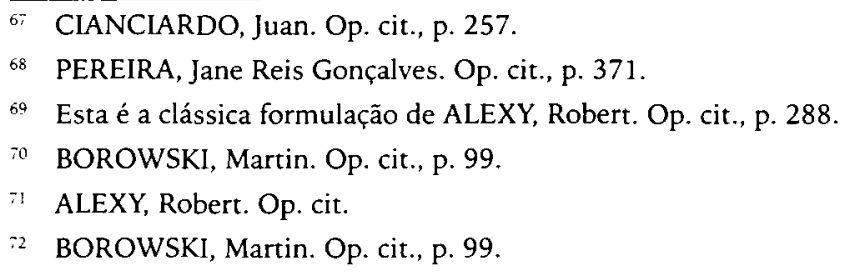


leram restrições para preservação de outros direitos e princípios, o de menor raio (núcleo essencial), por sua essencialidade, não admite qualquer tipo de restrição, sob pena de perda do sentido útil do direito respectivo. ${ }^{73}$

Fala-se, ainda, em uma teoria mista, que concebe a existência de uma dupla barreira às restrições legislativas: no círculo de maior raio, a legitimidade das restrições legislativas condiciona-se à observância da proporcionalidade; no de menor raio, tem-se o núcleo essencial, entendido como um âmbito de proteção incondicionado, na medida em que incompatível com qualquer restrição legislativa. Parece claro, todavia, que não se cuida, propriamente, de fusão das teorias relativa e absoluta, mas de variação da teoria absoluta, ante a concepção do núcleo essencial como uma esfera de proteção insuperável e que prescinde de ponderação. ${ }^{74}$

Ambas as teorias são objeto de severas críticas. A teoria absoluta é acusada de não prover instrumentos metodológicos adequados para a identificação segura do núcleo essencial, circunstância que daria azo a um amplo subjetivismo. ${ }^{75}$ Por outro lado, assevera-se que esta concepção não fornece explicações satisfatórias para as hipóteses em que se verifica "a cedência, por vezes integral, de todo e qualquer direito fundamental" em hipóteses em que o conflito não possa ser resolvido pela compressão recíproca dos direitos em cotejo. ${ }^{76}$

A par de sofrer todas as críticas dirigidas à ponderação e à proporcionalidade, a teoria relativa é ainda adicionalmente criticada por transformar a garantia do núcleo essencial, mencionada em diversos textos constitucionais e em iterativa jurisprudência dos Tribunais Constitucionais, em um "fantasma" de proteção, porquanto, respeitada a proporcionalidade, qualquer restrição legislativa seria admitida, inclusive aquelas que privassem o direito fundamental de qualquer sentido útil. Neste viés, aduz-se que a negativa de vinculação do legislador a um núcleo mínimo de sentido preestabelecido constitucionalmente atentaria contra as noções de rigidez e de supremacia da Constituição, porquanto conferiria ao legislador o poder de restringir ilimitadamente os direitos fundamentais, os quais perderiam completamente o seu efeito vinculante em face do Parlamento. ${ }^{77}$

No Brasil, destaca-se o esforço de Humberto Ávila em extremar os princípios da proporcionalidade e da salvaguarda do núcleo essencial, que denomina de "proibição do excesso". Ávila salienta que o exame do respeito ao núcleo essencial

73 NOVAIS, Jorge Reis. Op. cit., p. 782.

i4 PEREIRA, Jane Reis Gonçalves. Op. cit.

75 Salienta, nesse particular, Jorge Reis Novais que "apesar da sua multiplicidade, as tentativas de delimitaçāo substancialista de um núcleo ou âmbito essencial dos direitos fundamentais não são satisfatórias enquanto produção de resultados juridicamente comprováveis e operativos e, no fundo, não o são porque a tarefa de distinçāo substancialista, dentro do âmbito de protecção de cada direito fundamental, entre os elementos que seriam aureolares ou acidentais nāo é, pura e simplesmente, exeqüivel, tanto quanto, como diz Luhmann, nāo podemos conhecer a essência da essência". NOVAIS Jorge Reis. Op. cit., p. 788.

76 Ibidem, p. 783.

" MENDES, Gilmar Ferreira. Op. cit, p. 39. 
não envolve necessariamente o emprego dos subprincípios da adequação, da necessidade e da proporcionalidade em sentido estrito, no bojo de uma relação entre meio e fim, como se dá na proporcionalidade, mas se restringe à constatação de que nenhuma medida pode restringir excessivamente um direito fundamental, sejam quais forem as razões que a motivem. ${ }^{-8}$

À guisa de ilustração, Humberto Ávila cita a edição pelo poder público de ato normativo que obrigue os supermercados de determinada região a etiquetarem os produtos vendidos no seu estabelecimento. À vista de cuidar-se de medida que se destina a promover um fim (proteção dos consumidores), atingindo colateralmente o princípio da livre iniciativa, deve ser aplicado o princípio da proporcionalidade com o fito de solucionar o conflito. Considera o ilustre publicista gaúcho ser plausível concluir que a alvitrada medida passa no (i) exame da adequaçāo, porquanto etiquetar produtos contribui para a proteção dos consumidores; e também (ii) no crivo da necessidade, pois medidas alternativas, como a implantação do código de barras, protegem de forma menos intensa o consumidor. Todavia, poder-se-ia entender que a medida não passa (iii) no teste da proporcionalidade em sentido estrito, já que o grau de restrição causado ao princípio da livre iniciativa pela obrigação de etiquetar os produtos $(v \cdot g$. custos administrativos, necessidade de os produtos serem etiquetados sempre que os preços mudem, repasse dos custos ao consumidor, abandono do moderno sistema de código de barras etc.) superaria o grau de promoção do princípio da proteção dos consumidores (proteção de uma minoria desatenta em detrimento da média de consumidores que já é protegida por outros meios). Embora tal medida não tenha passado no teste da proporcionalidade em sentido estrito, atentando, portanto, contra o princípio da proporcionalidade, parece claro que a sua eventual adoção mantém incólume o núcleo essencial do direito à livre iniciativa, ${ }^{79}$ vez que a obrigação de etiquetar produtos não levará os empresários à ruína, inviabilizando o exercício de atividade econômica lícita.

Ainda que se possa discutir o mérito da solução apresentada, parece claro que o exemplo utilizado, ao evidenciar que uma medida pode ser considerada desproporcional não obstante se mantenha intocado o núcleo essencial do direito restringido, distingue os testes da proporcionalidade e da proteção do núcleo essencial. Contribui, portanto, para a adoção da variação da teoria absoluta antes exposta, que preconiza que os direitos fundamentais se estruturam na forma de dois círculos concêntricos: entre o limite do círculo mais amplo e o do menos amplo é estabelecida uma camada de proteção menos intensa, em que são toleráveis restrições compatíveis com a proporcionalidade; já dentro do círculo mais restrito (núcleo essencial) se vislumbra o cerne do direito, insuscetível de restrição de qualquer sorte.

\footnotetext{
-8 ÁVILA, Humberto Bergman. Teoria dos princípios: da definiçāo à aplicaçāo dos princípios jurídicos. p. 98 .

79. Ibidem, p. 99-100.
} 
Saliente-se, por oportuno, que a doutrina vem percebendo uma certa prevalência da teoria absoluta na jurisprudência da Cortes Constitucionais alemãa, ${ }^{80}$ espanhola $^{81}$ e portuguesa, ${ }^{82}$ por exemplo. Embora o Supremo Tribunal Federal brasileiro tenha passado ao largo da discussão travada pelos adeptos das teorias absoluta e relativa, de sua jurisprudência pode-se inferir o entendimento de que o legislador se encontra materialmente vinculado a um núcleo mínimo de sentido dos direitos fundamentais, que deflui da sua própria positivação constitucional. ${ }^{83}$

No que toca especificamente à restrição de direitos fundamentais por emendas constitucionais, o art. $60, \$ 4^{\circ}$, ao estatuir que "não será objeto de deliberação emenda constitucional tendente a abolir [...]" as cláusulas pétreas, ao nosso ver, torna inequívoco que não se veda toda e qualquer restrição às cláusulas pétreas, mas tão-somente aquelas que venham a aniquilar, tendencial ou efetivamente, a sua substância, a sua identidade, os elementos que lhes são absolutamente essenciais e inerentes, enfim, precisamente o seu núcleo essencial. ${ }^{84}$ Daí se infere que, quando menos, no plano das emendas constitucionais, o direito constitucional positivo dá lastro à possibilidade de restrição dos princípios erigidos ao status de cláusulas pétreas (teoria externa), assim como ao reconhecimento da existência de un núcleo mínimo de sentido indisponível à configuração do poder reformador (teoria absoluta).

Efetivamente, não apenas a literalidade do art. $60, \$ 4^{\circ}$, inciso IV da Constituição de 1988 indica a necessidade de vinculação material do poder constituinte reformador ao núcleo essencial dos direitos fundamentais, como a própria lógica da previsão de cláusulas pétreas conduz a tal ilação. Explica-se: faria algum sentido que o constituinte originário retirasse determinadas matérias do alcance do poder de reforma da Constituição, se por intermédio desta prerrogativa se pudesse suprimir a identidade do direito respectivo? Parece evidente que não. Assim, revela-se nítido que a efetiva retirada de determinados conteúdos constitucionais essenciais do poder constituinte derivado, tal qual intentado pelo constituinte originário ao estatuir as cláusulas pétreas, pressupõe que se lhes atribua um núcleo de sentido mínimo, absolutamente intangível por intervençōes restritivas oriundas de emendas constitucionais, ainda que se reconheça a impossibilidade da determinação do núcleo essencial de todo e qualquer direito fundamental com abstração das particularidades dos casos concretos que suscitem a sua aplicação.

\footnotetext{
80 BVerfGE 34, 238 (245), BVerfGE 194 (201) apud ALEXY, Robert. Op. cit., p. 288 ss.

81 STC 11/1981 apud CIANCIARDO, Juan. Op. cit., p. 261 ss.

82 Acórdãos TC 8/84, DR II, 3/5/86; TC 76/85, DR II 8/6/85; TC 31/87, DR II, 1/4/87 apud CANOTILHO, José Joaquim Gomes. Direito constitucional e teoria da Constituição. p. 633.

83 Ver, neste sentido, a sistematização da jurisprudência do STF da lavra de BIAGI, Cláudia Perotto. A garantia do núcleo essencial dos direitos fundamentais na jurisprudência constitucional brasileira. Porto Alegre: Sergio Antonio Fabris Editor, 2005. p. 99 ss.

84 V. NOVELLI, Flavio Bauer. Norma constitucional inconstitucional? A propósito do art. $2^{\circ}, \$ 2^{\circ}$, da EC no 3/93. Revista Forense, v. 330, p. 82 ss, 1995. A bem da verdade, cumpre repisar que o princípio da salvaguarda do núcleo essencial é um dos limites às restriçôes dos direitos fundamentais, atuando conjuntamente com os demais.
} 
Pode-se dizer que o STF vem flertando com a adoção desta perspectiva no âmbito específico dos limites materiais ao poder de reforma. No julgamento da ADIn $n^{\circ} 3128-7,{ }^{85}$ em que se impugnava a contribuição previdenciárias incidente sobre os proventos dos servidores inativos, instituída pelo art. $4^{\stackrel{ }{ }}$, da Emenda Constitucional $n^{\circ} 41$, de 19.12.2003 (Reforma Previdenciária), salientou o Min. Joaquim Barbosa que as cláusulas pétreas consistiam em "instrumento hermenêutico poderoso, de extrema utilidade para a preservação do núcleo essencial de valores constitucionais", enquanto o Min. Gilmar Mendes averbou que o grande desafio da jurisdição constitucional consiste em "não permitir a eliminação do núcleo essencial da Constituição", nem valer-se de interpretação ortodoxa que impeça a mudança. ${ }^{86}$

Esta também parece ser a posição adotada pela doutrina pátria mais abalizada. Em artigo clássico, Flavio Bauer Novelli, na esteira de Klaus Stern, já em 1995 interpretava a expressão tendente a abolir como destinada a vedar apenas as emendas capazes de suprimir, destruir, ou tornar impraticáveis os direitos fundamentais, proscrevendo, enfim, as que toquem o seu conteúdo essencial. ${ }^{87}$ Perspectiva similar foi esposada por Ingo Sarlet, para quem a proteção superconstitucional outorgada aos direitos fundamentais

não alcança as dimensōes de uma absoluta intangibilidade, já que apenas uma abolição (tendencial ou efetiva) se encontra vedada. Também aos direitos fundamentais se aplica a já referida tese da preservação do núcleo essencial, razão pela qual até mesmo eventuais restriçōes, desde que nãoinvasivas do cerne do direito fundamental, podem ser toleradas. Que tal circunstância apenas pode ser aferida à luz do caso concreto e considerando as peculiaridades de cada direito fundamental parece não causar maior controvérsia. ${ }^{88}$

\section{Proposições objetivas finais}

Seguem, de forma esquemática e resumida, as principais conclusões obtidas ao longo do texto:

1. Emenda constitucional que, simplesmente, modifique dispositivo constitucional que veicule cláusula pétrea não apresenta, necessariamente,

\footnotetext{
85 BRASIL. Supremo Tribunal Federal. Açāo Direta de Inconstitucionalidade n⿳0 3128-7. Requerente: Associação Nacional dos Procuradores da República. Requerido: Congresso Nacional. Relator: Min. Ellen Gracie, 18 de agosto de 2004. Disponível em: <http://www.stf.gov.br >. Acesso em: 12 jul. 2006; DJ 18.2.2005, Ementário no 2180-3, p. 450-774.

86 DJ 18.2.2005, Ementário no 2180-3, p. 491-625.

s: NOVELLI, Flavio Bauer. Op. cit., p. 63-89.

88 SARLET, Ingo Wolfgang. A eficácia dos direitos fundamentais. 2. ed. Porto Alegre. Livraria do Advogado, 2001. p. 368.
} 
vício de inconstitucionalidade. Ao contrário, a inconstitucionalidade da respectiva emenda constitucional deriva da intervenção abusiva do constituinte reformador sobre a norma de direito fundamental objeto de proteção superconstitucional.

2. As teorias interna e externa oferecem respostas díspares acerca da possibilidade de o legislador (consituinte-reformador ou ordinário) introduzir efetivas restrições aos direitos fundamentais. A teoria interna considera tal medida incompativel com a supremacia da Constituição, porquanto implicaria a admissão de que o legislador, apesar de teoricamente vinculado à Constituição, pudesse negar aplicabilidade a este diploma normativo, do que resultaria uma supervalorização das normas infraconstitucionais em detrimento das constitucionais.

3. Já a teoria externa salienta a inevitabilidade de o legislador, especialmente sob a égide de Constituiçôes compromissórias, impor restrições recíprocas a direitos fuindamentais quando estes entrarem em conflito com outros princípios constitucionais. Com efeito, tendo em vista a estrutura principiológica de boa parte das normas de direito fundamental, caracterizada pela baixa densidade normativa e pela intensa carga valorativa, a necessidade de o legislador impor restrições mútuas aos princípios conflitantes se afigura patente. Ademais, ocultar o problema em nada contribui para a busca de racionalidade e objetividade à interpretação e aplicação dos direitos fundamentais, conduzindo, ao contrário, a um maior risco de decisionismo judicial.

4. As restrições impostas pelo legislador aos direitos fundamentais distinguem-se, quanto à origem da restrição, em: (i) expressamente estatuídas pela Constituição, (ii) expressamente autorizadas pela Constituição, e (iii) implicitamente autorizadas pela Constituição; e, quanto à natureza da restrição, em restriçōes legislativas e aplicativas.

5. São limites às restriçōes aos direitos fundamentais ("limites dos limites"): (i) o princípio da reserva de lei restritiva, (ii) o princípio da clareza e da determinação mínima das normas restritivas, (iii) a proibição de restrições casuísticas, (iv) o princípio da proporcionalidade e (v) o princípio da proteção do núcleo essencial. A tais princípios soma-se um importante standard de ponderação: no controle da constitucionalidade de emendas constitucionais restritivas de direitos fundamentais, o Judiciário deve adotar uma postura de mais intensa autocontenção do que quando a restrição provier de lei, na medida em que a sua postura de autocontenção deve ser diretamente proporcional à solidez e à qualidade deliberativa do consenso obtido no seio do Congresso Nacional. Explica-se: partindo-se da premissa de que a superaçāo do processo qualificado referente às emendas constitucionais (v. limites materiais, formais e circunstanciais ao poder de reforma da Constituição, previstos no art. 
60 da Constituição de 1988) tende a apresentar maior solidez e qualidade deliberativa do que o processo legislativo ordinário, deve o Judiciário atuar com maior cautela na aferição da constitucionalidade de emendas constitucionais do que no controle da constitucionalidade de leis em geral.

6. O objeto e a natureza da proteção promovida pelo princípio da salvaguarda do núcleo essencial é, contudo, alvo de sérias controvérsias. Quanto ao primeiro aspecto, opóem-se as teorias objetiva e subjetiva. A primeira considera que o princípio da salvaguarda do núcleo essencial não torna imune de supressão a liberdade concreta desta ou daquela pessoa (direito subjetivo), mas o direito fundamental enquanto instituição objetiva do sistema jurídico, de forma a tutelar-se apenas a sua permanência abstrata no direito positivo. Já a teoria subjetiva sustenta, inversamente, que o objeto de proteção do princípio em apreço é o direito subjetivo do indivíduo, sob pena de negar-se qualquer proteção efetiva ao direito fundamental respectivo, notadamente no âmbito de um regime que não se reconheça como totalitário. Todavia, tendo em vista a complementaridade das dimensões subjetiva e objetiva dos direitos fundamentais, faz-se mister engendrar uma teoria mista que proteja os direitos fundamentais enquanto direitos subjetivos e instituições objetivas de alta densidade valorativa.

7. Quanto à natureza da proteção, opõem-se as teorias relativa e absoluta. A primeira considera o núcleo essencial "aquilo que sobra após a ponderação”, acabando por confundir os princípios da proteção do núcleo essencial e da proporcionalidade. Já a teoria absoluta vislumbra o núcleo essencial dos direitos fundamentais como um núcleo intangível cuja identificação independe de ponderação. A posição adotada no presente artigo preconiza que os testes da proporcionalidade e da proteção do núcleo essencial são distintos, de maneira que os respectivos princípios se consubstanciam em parâmetros autônomos de controle da constitucionalidade de leis ou emendas constitucionais restritivas dos direitos fundamentais.

\section{Referências bibliográficas}

ALEXY, Robert. Teoría de los derechos fundamentales. Madrid: Centro de Estudios Constitucionales, 1997.

ANDRADE, José Carlos Vieira de. Os direitos fundamentais na Constituição portuguesa de 1976. 2 ed. Coimbra: Almedina, 2001.

ÁVILA, Humberto Bergman. A distinção entre princípios e regras e a redefinição do dever da proporcionalidade. Revista de Direito Administrativo, 215, 1999. 
ÁVILA, Humberto Bergman. Sistema constitucional tributário. São Paulo: Saraiva, 2004.

Teoria dos princípios: da definiçāo à aplicação dos princípios jurídicos. 4. ed. São Paulo: Malheiros, 2004.

BARCELLOS, Ana Paula de. Ponderação, racionalidade e atividade jurisdicional. Rio de Janeiro: Renovar, 2005.

BARROS, Suzana de Toledo. O principio da proporcionalidade e o controle de constitucionalidade das leis restritivas de direitos fundamentais. Brasília: Brasília Jurídica, 2003.

BARROSO, Luís Roberto. Interpretação e aplicação da Constituição: fundamentos de uma dogmática constitucional transformadora. Rio de Janeiro: Saraiva, 1999.

BLAGI, Cláudia Perotto. A garantia do núcleo essencial dos direitos fundamentais na jurisprudência constitucional brasileira. Porto Alegre: Sergio Antonio Fabris, 2005.

BOBBIO. Norberto. Teoria do ordenamento jurídico. 10. ed. Brasília: Editora UnB, 1999.

BOROWSKI, Martin. La estructura de los derechos fundamentales. Bogotá: Universidad Externado de Colombia, 2003.

BUECHELE, Paulo Armínio Tavares. O princípio da proporcionalidade e sua interpretação da constituição. Rio de Janeiro: Renovar, 1999.

CANOTILHO, José Joaquim Gomes. Direito constitucional e teoria da Constituição. Coimbra: Almedina, 1999.

CIANCLARDO, Juan. El conflictivismo en los derechos fundamentales. Pamplona: EUNSA, 2000 .

FARIAS, Edilsom Pereira de. Colisão de direitos: a honra, a intimidade, a vida privada versus a liberdade de expressão e informação. Porto Alegre: Sergio Antonio Fabris, 2000.

FIORAVANTI, Maurizio. Los derechos fundamentales: apuntes de la historia de las constituciones. 4. ed. Madrid: Trotta, 2003.

GUERRA FILHO, Willis Santiago. Princípio da proporcionalidade e teoria do direito. In: GRAU, Eros Roberto; GUERRA FILHO, Willis Santiago (Org.). Direito constitucional: estudos em homenagem a Paulo Bonavides. São Paulo: Malheiros, 2001.

HESSE, Konrad. Elementos de direito constitucional da República Federal da Alemanha. Porto Alegre: Sergio Antonio Fabris, 1999.

MELLO, Celso Antônio Bandeira de. Conteúdo jurídico do princípio da igualdade. São Paulo: Malheiros, s/d. 
MENDES, Gilmar Ferreira. Plebiscito - EC 2/92 (Parecer). Revista Trimestral de Direito Público, 7/105/1994.

. Direitos fundamentais e controle de constitucionalidade. São Paulo: Celso Bastos, 1999.

. Os limites dos limites. In: MENDES, Gilmar Ferreira et al. Hermenêutica constitucional e direitos fundamentais. Brasília: Brasília Jurídica, 2000.

NOVELLI, Flavio Bauer. Norma constitucional inconstitucional? A propósito do art. 2º p. 2, da EC nº 3/93. Revista Forense, v. 330, 1995.

NOWAK, John E.; ROTUNDA, Ronald D. Constitutional law. St. Paul: Thomson West, 2004.

OTTO Y PARDO, Ignacio de. La regulación del ejercicio de los derechos y libertades: la garantía de su contenido esencial en el articulo 53.1 de la constitución. In: MARTÍN-RETORTILLO, Lorenzo; OTTO Y PARDO, Ignacio de. Derechos fundamentales y constitución. Madrid: Civitas, 1992.

PEREIRA, Jane Reis Gonçalves. Interpretação constitucional e direitos fundamentais. Rio de Janeiro: Renovar, 2006.

PEREZ-LUÑO, Antonio Henrique. Los derechos fundamentales. Madrid: Tecnos, 1998.

PIÇARRA, Nuno. A separação de poderes como doutrina e princípio constitucional. Coimbra: Coimbra Editora, 1989.

PULLIDO, Carlos Bernal. El principio de proporcionalidad y los derechos fundamentales: el principio de proporcionalidad como criterio para determinar el contenido de los derechos fundamentales vinculantes al legislador. Madrid: Centro de Estudios Político y Constitucionales, 2003.

QUEIROZ, Cristina. Direitos fundamentais: teoria geral. Coimbra: Coimbra Editora, 2003.

SARLET, Ingo Wolfgang. Direitos sociais: o problema de sua proteção contra o poder de reforma na Constituição de 1988. Revista de Direito Constitucional e Internacional, ano 12, n 46, jan./mar. 2004.

SARMENTO, Daniel. A ponderação de interesses na Constituição de 1988. Rio de Janeiro: Lumen Juris, 2002.

SHOELLER, Heinrich. O princípio da proporcionalidade no direito constitucional e administrativo da Alemanha. Interesse Público, v. 1, no 2, 1999.

SOUZA NETO, Cláudio Pereira. Jurisdição constitucional, democracia e racionalidade prática. Rio de Janeiro: Renovar, 2002. 
SILVA, Luís Virgílio Afonso da. O proporcional e o razoável. Revista dos Tribunais, 798, abr. 2002.

STEINMETZ, Wilson Antônio. Colisāo de direitos fundamentais e princípio da proporcionalidade. Porto Alegre: Livraria do Advogado, 2001.

STUMM, Raquel Denize. O princípio da proporcionalidade no direito constitucional brasileiro. Porto Alegre: Livraria do Advogado, 1995.

TORRES, Ricardo Lobo. A legitimação dos direitos humanos e os princípios da ponderação e da razoabilidade. In: TORRES, Ricardo Lobo (Org.). Legitimação dos direitos humanos. Rio de Janeiro: Renovar, 2002.

VEGA, Pedro de. La reforma constitucional y la problematica del poder constituyente. Madrid: Tecnos, 2000.

\section{Jurisprudenciais}

ADIn n 939-DF, Tribunal Pleno, STF, RTJ 151.

ADIn nº 885, Rel. Min. Sepúlveda Pertence, DJ $1^{\circ}$ out. 1993.

ADIn $n^{\circ}$ 3128-7, Rel. Min. Ellen Gracie, DJ 18 ago. 2004. 